\title{
The Impact of the Application of IT Governance According to (COBIT 5) Framework in Reduce Cloud Computing Risks
}

\author{
Samer Okour ${ }^{1}$ \\ ${ }^{1}$ Accounting Department, The World Islamic Sciences \& Education University, Jordan \\ Correspondence: Samer Okour, Accounting Department, The World Islamic Sciences \& Education University, \\ Jordan. E-mail: samer_okour@yahoo.com
}

Received: May 1, 2019

Accepted: May 30, 2019

Online Published: June 25, 2019

doi:10.5539/mas.v13n7p25

URL: https://doi.org/10.5539/mas.v13n7p25

\begin{abstract}
The study aimed at identifying the impact of the application of IT governance represented by (Planning and Organization, Possessiveness and Implementation, Support and Delivery, Monitoring and Evaluation, and Guidance and Control), using (COBIT 5) framework to reduce the risks associated with cloud computing (Identity and Access Management, Data protection, Virtual operating risk, IT support, and Organization) in the Jordanian industrial companies public shareholding from the perspective of Jordanian Certified Public Accountants. The study follows sequential procedures as a strategy for the mixed methods that have been applied. The researcher collects qualitative data that are quantitatively analyzed. A questionnaire was used to achieve the purpose of the study. The study population included all external accountants practicing auditing in Jordan, who number until the end of 2017 (384), a simple random sample was drawn, the sample included (192) auditors.

The study concluded that all the decisions of the (COBIT5) Committee including Planning and Organization, Possessiveness and Implementation, Support and Delivery, Monitoring and Evaluation, and Guidance and Control affect the reduction of the risk of cloud computing in terms of identity and Access Management, Data protection, Virtual operating risk, IT support, and Organization the Jordanian industrial companies public shareholding from the perspective of Jordanian Certified Public Accountants. Based on the findings of the study, the researcher recommends that Jordanian industrial companies need to activate the role of security controls and increase the level of application against the environmental risks surrounding the company likely to occur as a result of the application of cloud computing. It is also necessary to update and develop information technologies, especially those related to technology.
\end{abstract}

Keywords: IT Governance, Cloud Computing, Risks, (COBIT 5) Framework

\section{Introduction}

The information and communication revolution has led organizations' to interaction with all types of data and information and their increased use of ICTs in managing its affairs. This is due to the role played by this technology in constructing successful institutions and pushing them to create featured relationships with their customers, which will positively reflect on their market share (Behara\& Srikanth, 2007).As well as access to outputs quality that enables users, managers and decision-makers to make the proper decisions by carefully identifying, planning and organizing corporate IT strategies, determining how they are gain access, using their resources and infrastructure, and delivering them to various levels of management, and the maintenance these systems over control and monitoring. Detlor et al. (2010) say: "The evolution of information technology pushes the accounting profession to modernize and develop its tools and methods so that it can continue to provide high-quality services. Which has led to the emergence of IT governance".

Cloud computing is one of the most advanced information technologies Which has been created by the advancement and evolution of IT systems as a new service originative to smooth the work for both organizations and individuals. This service smoothes the work of users and helps to sustain the scope of carpetbaggers (Sah et al., 2014). As organizations endeavor to take advantage of information technology to reduce their business costs and increase their benefits, so they have explore to benefit from external parties that supply many resources for the organizations to manage and supplying its services through users arrival of this technology to all applications and services from any place and at any time through the Internet in a way that ensures its sustainability (Mazhar et al., 2015). 
Despite the importance of the role played by information and cloud computing and the benefits achieved by the technology, however, most attention focused on security related aspects and risks resulting therefrom (Aljoumah et al., 2015). This has made it more important to have control tools that control information systems work and technology in companies. Which has shown the need to adopt control frameworks governing information technology in companies and institutions. These frameworks include: Control objectives for Information and Related Technology (COBIT). Which was established as an IT control tool through 34 high-level oversight objectives, involve four dimensions which are: planning, organization, possessiveness, implementation, delivery, monitoring and evaluation (Andry\& Hartono, 2017). Recently, the COBIT5 Framework for IT Risk Management has become a tool to support managers, auditors and users in understanding their IT systems, as well as helping to improve their corporate governance model, leading to the choice of safety level and the necessary control to efficiently and effectiveness protect assets Company.

Based on the above discussion, the current study attempts to demonstrate the impact of IT governance on reducing the risk of cloud computing under (COBIT 5) framework

\subsection{Study Objectives}

The main objective of the study is to identify the impact of the application of IT governance represented by (Planning and Organization, Possessiveness and Implementation, Support and Delivery, Monitoring and Evaluation, and Guidance and Control), using (COBIT 5) framework to reduce the risks associated with cloud computing in companies and institutions of various types.

\subsection{Study Problem}

Cloud computing is one of the modern technology systems that offer many services and advantages to organizations in many fields. The vast majority of users are keen to take advantage of them. However, the human, legislative, physical and security risks associated with using cloud computing are among the main obstacles to the organization's implementation of this technology, which we have to find a solution to reduce. The most prominent of these solutions is the adoption of (COBIT 5) by organizations areas of technology governance the information.

The problem of the study is centered on trying to answer the following question: is there an impact of the decisions of (COBIT 5) Committee which is represented in (planning, organization, possessiveness, implementation, support, delivery, monitoring, evaluation, guidance, and control) in reducing the risks of cloud computing which is represented in(Identity and Access Management, Data protection, Virtual operating risk, IT support, and Organization) In the Jordanian industrial companies public shareholding from the perspective of Jordanian Certified Public Accountants?

\subsection{Study Importance}

The importance of this study stems from the importance of its subject, where is the protection of information security of the most prominent modern-day issues, It also highlights the importance of the study from the modernity of the subject. It is expected to constitute a scientific addition to the various stakeholders and may contribute to best practices to secure the information resources of their institutions, as well as the importance of the study stems from the importance of risk assessment associated with cloud computing with the use of (COBIT 5) framework to reduce the risk of cloud computing in companies and institutions of all types.

\subsection{Study Hypotheses}

Based on the questions of the study problem and in order to achieve its objectives, the following hypotheses were formulated:

Ho: There is no significant statistical effect at the level of $(\alpha \leq 0.05)$ for the decisions of the (COBIT5) Committee (Planning and Organization, Possessiveness and Implementation, Support and Delivery, Monitoring and Evaluation, and Guidance and Control)in reducing the risk of cloud computing (Identity and Access Management, Data protection, Virtual operating risk, IT support, and Organization) In the Jordanian industrial companies public shareholding from the perspective of Jordanian Certified Public Accountants.

This hypothesis is divided into the following sub-hypotheses:

Ho1: There is no significant statistical effect at the level of $(\alpha \leq 0.05)$ for planning and organization in reducing the risk of cloud computing (Identity and Access Management, Data protection, Virtual operating risk, IT support, and Organization) In the Jordanian industrial companies public shareholding from the perspective of Jordanian Certified Public Accountants.

Ho2: There is no significant statistical effect at the level of $(\alpha \leq 0.05)$ for Possessiveness and implementation in reducing the risk of cloud computing (Identity and Access Management, Data protection, Virtual operating risk, 
IT support, and Organization) In the Jordanian industrial companies public shareholding from the perspective of Jordanian Certified Public Accountants.

Ho3: There is no significant statistical effect at the level of $(\alpha \leq 0.05)$ for service support and delivery in reducing the risk of cloud computing (Identity and Access Management, Data protection, Virtual operating risk, IT support, and Organization) In the Jordanian industrial companies public shareholding from the perspective of Jordanian Certified Public Accountants.

Ho4: There is no significant statistical effect at the level of $(\alpha \leq 0.05)$ for monitoring and evaluation in reducing the risk of cloud computing (Identity and Access Management, Data protection, Virtual operating risk, IT support, and Organization) In the Jordanian industrial companies public shareholding from the perspective of Jordanian Certified Public Accountants.

Ho5: There is no significant statistical effect at the level of $(\alpha \leq 0.05)$ for guidance and control in reducing the risk of cloud computing (Identity and Access Management, Data protection, Virtual operating risk, IT support, and Organization) In the Jordanian industrial companies public shareholding from the perspective of Jordanian Certified Public Accountants.

\section{Theoretical Framework}

\subsection{IT Governance}

The term "IT governance" is derived from the term "corporate governance", which emerged after the recent financial crises and scandals that hit major international companies (Sasaki \&Yonezawa, 2010). The Institute for Information Technology Governance has noted that IT governance is the complementary part of corporate governance and consists of leadership, organizational structure and processes that emphasize technology support in the organization and ensure the achievement of the organization's strategy and objectives(Mirela, 2010).The term IT governance has been commonly used to refer to encouraging desired behaviors in the use of information technology by defining decision-making rights and the accountability framework, ie, using organizational structures, leadership and operational actions that ensure IT supports the organization's strategy and objective (Weill \& Ross, 2004).

Moeller (2013) defined IT governance as "a set of policies and applications by both senior management and IT management in the organization to control the design and implementation of an information technology strategy to improve the activities and processes of the organization, through the verification of the ability of information technology to meet the needs contained in the strategies of the Organizations". While Solomon et al. (2003) argues that: "IT governance means information governance, which refers to the establishment and organization of relations between technology service providers and internal and external users of this information". Freeland(2016) believes that IT governance is based on the interest in using applications and technologies in the activities and processes related to the organization's IT-based strategy, which conforms to the overall strategy of the Organization, as well as the enactment of rules, laws, procedures and policies that ensure that IT units and divisions are adhering to the overall strategy established by The Organization, and thus represents the means by which society ensures the interest of the Department in the interests of all parties.

\subsection{The importance of IT governance}

The importance of IT governance is demonstrated by its significant role in driving organizations towards achieving their goals (Behara\& Srikanth, 2007), which is achieved through the achievement of flexibility in information technology and in the structuring of information systems operations(Detlor et al., 2010), and activate the role of management and control of information technology activities in the organization, to take note of the risks resulting from them, and increasing the awareness of the importance of information technology in competitiveness and reducing the costs of investing in information technology (Lee et al., 2008).In addition to its role in allowing them to exchange information and applied techniques (Muelleret al., 2008).

\subsection{COBIT Framework for IT Governance}

COBIT framework for IT Governance is one of the most important developments in the area of technology governance, which was first published in the mid-1990s, specifically in 1996, by Information systems Audit and Control Association (ISACA), in order to reduce the difficulties faced by auditors under automated accounting systems, and also with the aim of creating a working guide for auditors in the IT environment. It also helps organizations to get maximum benefit from their information, understand the risks surrounding them, access the best of information opportunities, such as information of the customer, investor, employee, production, audit, speed of service, and customer time preservation (Hardy, 2006). 
COBIT Framework for IT Governance has witnessed many developments, the basis for all these developments was the IT audit, which makes it a comprehensive IT management framework. The final version of this framework (COBIT 5) was released in 2012, which emphasized the concept of information technology governance in the organization (De Haes \& Van Grembergen, 2015). The Information Systems Audit and Control Association (ISACA) has pointed out that this release provides a more comprehensive framework that helps organizations achieve their objectives in the areas of governance and IT management, where this version provides the necessary support to the Organization in the management of information technology in a comprehensive manner for the entire work taking into account the identification of functional areas and responsibilities, in addition to the interests of all internal and external beneficiaries of information technology (ISACA, 2012).

\subsection{Benefits of implementing COBIT 5}

The implementation of (COBIT 5) contributes to providing the organization with many benefits, such as increased compliance with relevant laws, regulations, and policies, improve the relationship between business needs and IT goals and increase financial return by obtaining greater value from investments in technology. It also provides guidance on how the empowerment factors contribute to the overall governance and risk management of any company seeking the mechanism for using information governance technology. These guidelines include the creation of efficient and effective risk management that promotes stakeholder value, the collection, assessment risk information, as well as the acceptable level of risk that the organization can bear (Oliver \&Lainhart, 2012).

\subsection{IT Fields and Controls under the COBIT 5 Framework}

IT fields and controls under the COBIT 5 framework include:

First: planning and Organization:

Planning and organization is the cornerstone for building IT governance and effective corporate governance. The planning and organization include a number of objectives, which are to coordinate the technology and the activities of the company through the planning process, whether short or medium term. Planning and organization work to ensure that IT management, where IT features are translated from the governance framework into real procedures and practices within the company (Romero et al., 2017). In addition to improving the process of strategic alignment (Preittigun et al., 2012), it also gives management a general description of the needs of stakeholders and the purpose of managing the structure of the company and also enables the identification of capacity and requirements (Cadete, 2015).

Second: Possessiveness and Implementation:

Possessiveness and implementation refers to the identification and acquisition of information technology requirements for the successful executives of business within the Company (Bakshi \& Eswar, 2018), and it includes: management of changes, acceptance, and conversion, program and project management, requirements management, and finally knowledge management (Romero et al., 2017).

Third: Support and Delivery:

Support and delivery focus on adding value to the IT system, providing data support and processing correctly to sustain business activities, maintaining continuity of information flow and making it permanently available to internal and external beneficiaries, and it includes: Operations management, asset management, service and event management, problems management, business continuity management, security management, and management of business process controls (Iqbal et al., 2016).

Fourth: Monitoring and Evaluation:

Monitoring and evaluation focuses on the existence of a follow-up and evaluation plan that describes what to follow, what activities are needed to conduct the monitoring and evaluation process, who is responsible for them, Monitoring and evaluation aims to monitor and evaluate performance and conformity,, monitor internal control system, and monitor and evaluate compliance with external requirements (Putri et al., 2017).

Fifth: Guidance and Control:

Monitoring is the collection and analysis of information relating to a project or program that takes place during the implementation of the project or program. Guidance and control include: Ensure transparency of stakeholders, ensure the delivery of benefits, ensure risk improvement, and ensure the improvement of resources (Abdel Basset, 2014).

\subsection{Cloud Computing}

Cloud computing has received considerable attention from many individuals and organizations, and it has received 
many definitions, for example, Onyegbula et al. (2011) defined cloud computing as "a computing method that provides widespread IT services as a service to external customers by using Internet technology". It has also been defined as a:"parallel and distributed system consisting of clusters of interconnected and virtualized computers that are dynamically provided and presented as single or unified computing resources based on agreements based on the level of service provided" (Buyya et al, 2009). Dimitriua and Mateia (2014) referred to Cloud Computing as a:"technical means, including processing and storage of accounting data and other applications and servers outside the company's site which provided by one of the providers of this service so that companies access them through the Internet".

Cloud computing offers its services in three forms: the first isInfrastructure as a Service (IaaS), which refers to a set of IT equipment owned, managed and maintained by the cloud provider to be used by cloud customers on an on-demand payment system basis (Mehta \& Panda, 2018).The secondisPlatform as a Service (PaaS), which provides parts of infrastructure and middleware without the need to manage resources containing software, this means allowing cloud customers to create and control their applications through the cloud. These services include databases, distribution, application development integration, and management tools (Pastore, 2013).And the third is Software as a Service (SaaS), which refers to the system that allows cloud customers to access applications and associated data without the complexity of purchasing and installing applications at home (Alkhalil et. al., 2013).

\subsection{Cloud Computing Security}

The issue of electronic cloud security is one of the most controversial issues. Some researchers believe that electronic cloud information management from an internal network that secures information security, others believe that electronic clouds can provide the necessary security to ensure the security and integrity of information (Reddy 2014).

Information security problems in the cloud are related to two aspects: the customer and the service provider. Both are responsible for many of the risks to the information in the e-draw, and both are required to provide protection, as he is committed to providing a strong infrastructure, tools, and secure storage. The role of cloud computing provider is to maintain and secure information in electronic clouds by focusing on many elements such as verifying the user's identity and making sure that he or she already has the account (Shaikh \&Sasikumar, 2013), protect data by keeping customer information and ensuring that it does not leak (Sun et al., 2014). Security applications and operating systems (Sen \& Tiwari, 2017).And physical security as the service provider must verify that the quality of the network, applications, and servers it uses are free of any security vulnerabilities (Bunkar\& Rai, 2017). And finally, the service provider must provide appropriate policies and procedures that ensure the rights of the customer and service provider (Chen et al., 2010).

\subsection{Corporate Risk Management in Accordance with IT Governance for Cloud Computing Accounting}

Risk management is defined as the process of identifying vulnerabilities and threats through the organization's structure, as well as designing appropriate measures to reduce their impact on IT resources. Risk management is a continuous process that begins with an assessment of the company's exposure to risk, identification of key risks, and when risks are identified, they should be minimized using the tools and controls. The main IT governance practices in risk management are as follows (Alslihat et al., 2018):

1. Analysis and evaluation of information technology risks.

2. Monitor and control the efficiency of internal controls.

3. Implement and apply controls to reduce IT risk.

4. Establish the necessary procedures to ensure transparency about the risks of importance to the institution.

5. Ensuring that IT services are sound, blocking information about persons without authority.

Based on IT governance practices, the use of information technology under the Cobit5 framework will reduce the time spent in the audit process. Thus reducing costs and improving the quality of the audit process (Michele et al., 2017).In addition, the existence of risks related to the security of computer information calls for providing the appropriate degree of information security and electronic protection of the accounting information systems in the company in order to ensure that the information technology used in the company helps to achieve its strategy and expand to achieve its objectives, build relationships, and processes to guide them to monitor the work of the company(Susanto, 2018).

\section{Method}

\subsection{Research Methodology}


This study is designed to determine the impact of IT governance with (COBIT 5) framework on reducing the risk of cloud computing in Jordanian industrial companies from the perspective of Jordanian Certified Public Accountants. The study follows sequential procedures as a strategy for the mixed methods that have been applied. The researcher collects qualitative data that are quantitatively analyzed. The study is exploratory in trying to reveal the possible impact of IT governance with (COBIT 5) framework on reducing the risk of cloud computing, but analytical in drawing conclusion. The results of the hypotheses test are analyzed, and the implication of hypotheses is determined to reach recommendations and conclusions. The researcher reviews the theoretical studies and researches to crystallize the foundations on which the theoretical framework is based. A questionnaire is used to achieve the purpose of the study.

\subsection{Sources of Data}

Qualitative data has been collected and then quantitatively analyzed. Qualitative data is suitable for the study because it is based on the views and trends of Jordanian Certified Public Accountants as the study try to determine the possible impact of IT governance with (COBIT 5) framework on reducing the risk of cloud computing. A questionnaire has been distributed, then the resulted data has been expressed in statistical figures as well as applying statistical tools needed to test the hypotheses. The sources of data for the study are classified into primary and secondary data. The primary data are the results of the questionnaire. The secondary data include books, previous studies, academic journals, etc., to formulate hypotheses and determine the theoretical framework of the study.

\subsection{Population and Sample of Study}

The study population included all external accountants practicing auditing in Jordan, who number until the end of 2017 (384), and because of the difficulty and cost of the comprehensive survey, a simple random sample was drawn, based on the Krejcie\& Morgan scale (Krejcie\& Morgan,1970). The sample included (192) auditors. The questionnaire was distributed to the sample of the study by the researchers personally and through e-mail. The number of questionnaires recovered was (184), of which (175) were valid for the statistical analysis, after excluding (9) questionnaires for incomplete.

\subsection{Reliability Test}

The study used Cronbach's Alpha to test the reliability of the study tool. The results revealed a Cronbach's Alpha Coefficient of (0.941) for all items. The variables of the study range from $(0.640)$ to $(0.894)$, which indicates that the questionnaire is reliable. The values of $\alpha$ of the study variables are listed in the following table (1).

Table (1). Reliability test of study tool

\begin{tabular}{|c|c|c|c|}
\hline Number & Variable & $\begin{array}{l}\text { Number } \\
\text { paragraphs }\end{array}$ & Reliability Coefficient $(\alpha)$ \\
\hline 1 & Planning and Organization & 9 & 0.823 \\
\hline 2 & Possessiveness and Implementation & 6 & 0.699 \\
\hline 3 & Support and Delivery & 8 & 0.648 \\
\hline 4 & Monitoring and Evaluation & 7 & 0.773 \\
\hline 5 & Guidance and Control & 6 & 0.757 \\
\hline Information 7 & chnology Controls & 36 & 0.910 \\
\hline 6 & Identity and Access Management & 6 & 0.743 \\
\hline 7 & Data protection & 6 & 0.721 \\
\hline 8 & Virtual operating risk & 5 & 0.742 \\
\hline 9 & IT support & 3 & 0.640 \\
\hline 10 & Organization & 3 & 0.762 \\
\hline \multicolumn{2}{|c|}{ Cloud Computing Risks } & 23 & 0.894 \\
\hline \multicolumn{2}{|c|}{ All paragraphs } & 59 & 0.941 \\
\hline
\end{tabular}


Table (2). Demographic data of the questionnaire

\begin{tabular}{llll}
\hline & Measure & Frequency (out of 175) & Percentage \\
\hline \multirow{3}{*}{ Education } & Bachelor's & 129 & $73.3 \%$ \\
& Master's & 25 & $14.3 \%$ \\
& PhD & 13 & $7.4 \%$ \\
& Other & 8 & $5.0 \%$ \\
& Accounting & $\mathbf{1 3 4}$ & $76.6 \%$ \\
& Finance and banks & $\mathbf{1 9}$ & $10.9 \%$ \\
Scientific specialization & Information Technology & $\mathbf{1 0}$ & $5.7 \%$ \\
& Economics & $\mathbf{5}$ & $2.8 \%$ \\
& Business Administration & $\mathbf{7}$ & $4.0 \%$ \\
& $<5$ & 15 & $8.6 \%$ \\
Years of Experience & $5-10 \mathrm{Y}$ & 24 & $13.7 \%$ \\
& $11-15 \mathrm{Y}$ & 67 & $38.3 \%$ \\
& $16-20 \mathrm{Y}$ & 53 & $30.3 \%$ \\
& $>20$ & 16 & $9.1 \%$ \\
\hline
\end{tabular}

Table (2) shows that the vast majority of the sample have bachelor's degrees (73.3\%) and the percentage of those holding a master's degree (14.3\%). This indicates that the external auditors have the scientific knowledge that enables them to practice the profession of auditing with sufficient knowledge. It was also found that the majority of respondents had sufficient knowledge of accounting and auditing. The percentage of scientific specialization (accounting) was (76.6\%) of the sample. This is confirmed by the percentage of scientific experience (from 10 years to less than 15 years) which reached (38.3\%). This percentage confirms that auditors have sufficient practical experience in auditing.

\subsection{Describe of Respondents Answers}

This section contains descriptions of respondents' answers in terms of mean, standard deviation, relative importance, and rank.

3.6.1 Information Technology Controls

Table (3). arithmetic averages, standard deviations, levels and relative importance of Information Technology Governance

\begin{tabular}{llrrrr}
\hline $\begin{array}{l}\text { Item } \\
\text { No. }\end{array}$ & Item & Mean & $\begin{array}{l}\text { Standard } \\
\text { Deviation }\end{array}$ & $\begin{array}{l}\text { Relative } \\
\text { Importance }\end{array}$ & Rank \\
\hline 1 & Planning and Organization & 3.899 & 0.538 & High & 4 \\
2 & Possessiveness and Implementation & 3.922 & 0.505 & High & 3 \\
3 & Support and Delivery & 4.021 & 0.407 & High & 1 \\
4 & Monitoring and Evaluation & 3.878 & 0.501 & High & 5 \\
5 & Guidance and Control & 3.982 & 0.537 & High & \\
Information Technology Governance & 3.940 & 0.391 & & High & \\
\hline
\end{tabular}

Table (3) show the average mean for all the Information Technology Governance is (3.940) while the average standard deviation is (0.391), and the relative importance of all Information Technology Governance combined is 'high'. The Support and Delivery rank as first, followed by the Guidance and Control, while the Monitoring and Evaluation rank as last. This result indicates the approval of the sample that the management of the industrial companies is interested in monitoring the company's operations and information technology to ensure compliance 
with the policies, strategies, laws, and regulations in this area. The company's strategic objectives are in line with IT decisions. This also shows how much attention the management of industrial companies has to maximize value added through the activities and operations of the company and IT resources, ensure optimal utilization of them, and tightly control the risks and threats of information technology.

3.6.2 Cloud Computing Risks

Table (4). Arithmetic averages, standard deviations, levels and relative importance of Cloud Computing Risks

\begin{tabular}{llrrlr}
\hline Item & Item & Mean & $\begin{array}{l}\text { Standard } \\
\text { Deviation }\end{array}$ & $\begin{array}{l}\text { Relative } \\
\text { Importance }\end{array}$ & Rank \\
No. & & $\mathbf{4 . 0 5 2}$ & $\mathbf{0 . 4 8 7}$ & High & $\mathbf{1}$ \\
\hline 1 & Identity and Access Management & $\mathbf{4 . 0 1 6}$ & $\mathbf{0 . 5 5 6}$ & High & $\mathbf{2}$ \\
2 & Data protection & $\mathbf{4 . 0 0 2}$ & $\mathbf{0 . 5 8 9}$ & High & $\mathbf{3}$ \\
3 & Virtual operating risk & $\mathbf{3 . 7 9 4}$ & $\mathbf{0 . 6 1 0}$ & High & $\mathbf{5}$ \\
4 & IT support & $\mathbf{3 . 9 4 3}$ & $\mathbf{0 . 7 6 7}$ & High & $\mathbf{4}$ \\
5 & Organization & $\mathbf{3 . 9 6 2}$ & $\mathbf{0 . 4 7 2}$ & & \\
Cloud Computing Risks & &
\end{tabular}

Table (4) show the average mean for all the Cloud Computing Risks is (3.962) while the average standard deviation is (0.472), and the relative importance of all Cloud Computing Risks combined is 'high'. The Identity and Access Management rank as first, followed by the Data protection, while the IT support rank as last. The results show that all cloud computing risks variables have emerged with high relative importance. This result indicates that the trends of the sample were toward approval that the Jordanian industrial public shareholding companies seeking to reduce the risks and threats generated by the use of technology and the efficiency and effectiveness of their procedures in order to reduce these risks and reduce the negative impact and damage to the company and its customers, Ensuring the integrity and validity of their data and information and maintaining them.

\subsection{Bivariate Pearson Correlation}

To ensure that data is free of multicollinearity, the linear correlation coefficient was calculated for each variable, the results were as follows:

Table (5). Multiple correlation matrix for independent variables

\begin{tabular}{|c|c|c|c|c|c|}
\hline Variable & $\begin{array}{l}\text { Planning and } \\
\text { Organization }\end{array}$ & $\begin{array}{l}\text { Possessiveness } \\
\text { and } \\
\text { Implementation }\end{array}$ & $\begin{array}{l}\text { Support and } \\
\text { Delivery }\end{array}$ & $\begin{array}{l}\text { Monitoring } \\
\text { and } \\
\text { Evaluation }\end{array}$ & $\begin{array}{l}\text { Guidance and } \\
\text { Control }\end{array}$ \\
\hline $\begin{array}{ll}\text { Planning } & \text { and } \\
\text { Organization } & \end{array}$ & 1 & & & & \\
\hline $\begin{array}{l}\text { Possessiveness and } \\
\text { Implementation }\end{array}$ & $0.316 * *$ & 1 & & & \\
\hline Support and Delivery & $0.282 * *$ & $0.169 \%$ & 1 & & \\
\hline $\begin{array}{l}\text { Monitoring and } \\
\text { Evaluation }\end{array}$ & $0.448 * *$ & $0.405 * *$ & $0.230 * *$ & 1 & \\
\hline $\begin{array}{l}\text { Guidance and } \\
\text { Control }\end{array}$ & $0.445 * *$ & $0.417 * *$ & $0.238 * *$ & $.571 * *$ & 1 \\
\hline
\end{tabular}

**statistically significant at the level of significance of $0.01, *^{*}$ statistically significant at the level of significance of 0.05

Table (5) shows that the highest value of the correlation coefficient was found between the independent variables (Monitoring and Evaluation) and (Guidance and Control), which reached (0.517), while the correlation coefficient between the other independent variables was lower, this indicates that there is no perfect correlation between 
independent study variables. Linear correlation coefficients above $(0.80)$ may be indicative of multicollinearity (Guajarati, 2004, 359). Therefore, it is possible to say that the study sample is free from the problem of multicollinearity.

\subsection{Hypotheses Test}

The study relied on multiple regression analysis to test the study hypotheses.

Table (6). Test results of the effect of (COBIT5) Committee Information Technology Governance in reducing the risk of cloud computing

\begin{tabular}{|c|c|c|c|c|c|}
\hline \multirow[t]{2}{*}{ Dependent Variable } & \multirow[t]{2}{*}{ Independent variables } & \multicolumn{4}{|c|}{ Coefficients Table } \\
\hline & & $\mathrm{B}$ & Standard error & $\begin{array}{l}\text { calculated } \\
\mathrm{T}\end{array}$ & Sig t* \\
\hline \multirow{5}{*}{$\begin{array}{l}\text { Reducing the risk of } \\
\text { cloud computing }\end{array}$} & Planning and Organization & 0.146 & 0.048 & $\mathbf{3 . 0 7 4}$ & 0.002 \\
\hline & $\begin{array}{l}\text { Possessiveness and } \\
\text { Implementation }\end{array}$ & 0.185 & 0.041 & 4.459 & 0.000 \\
\hline & Support and Delivery & 0.128 & 0.041 & 3.155 & 0.002 \\
\hline & Monitoring and Evaluation & 0.160 & 0.075 & 2.141 & 0.034 \\
\hline & Guidance and Control & 0.234 & 0.076 & 3.079 & 0.002 \\
\hline $\mathrm{R}^{2}$ & & & & & 0.679 \\
\hline Adj $R^{2}$ & & & & & 0.461 \\
\hline Calculated F value & & & & & 28.917 \\
\hline Sig. $F^{*}$ & & & & & 0.000 \\
\hline
\end{tabular}

*The effect is statistically significant at level $(\alpha \leq 0.05)$

The results of Table $(\mathbf{6})$ indicate that the correlation coefficient $(\mathrm{R}=\mathbf{0 . 6 7 9})$, refers to the relationship between independent and dependent variables, the effect of independent variables (Information Technology Governance) dimensions on the dependent variable (Reducing the risk of cloud computing) is statistically significant, Where the value of the calculated $\mathrm{F}$ is $\mathbf{( 2 8 . 9 1 7})$ and the level of significance $(\mathrm{Sig}=0.000)$ is less than $(0.05)$, where the value of the coefficient of determination $(\mathrm{R} 2=\mathbf{0 . 6 7 9})$ indicates that $679 \%$ of the variation in reducing the risk of cloud computing can be explained by the variation in (Information Technology Governance) combined.

The table of coefficients showed that the value of B at (Planning and Organization) reached (0.146) and that the value of $\mathrm{T}$ is (3.074) with the level of significance $(\mathrm{Sig}=\mathbf{0 . 0 0 2})$, which is less than 0.05 , indicating that the effect of this dimension is significant. Accordingly, we reject the first null hypothesis, and accept the alternative hypothesis: There is an effect at the level of $(\alpha \leq 0.05)$ for planning and organization in reducing the risk of cloud computing (Identity and Access Management, Data protection, Virtual operating risk, IT support, and Organization) In the Jordanian industrial companies public shareholding from the perspective of Jordanian Certified Public Accountants.

The table of coefficients showed that the value of B at (Possessiveness and Implementation) reached $(0.185)$ and that the value of $\mathrm{T}$ is (4.459) with level of significance ( $\mathrm{Sig}=\mathbf{0 . 0 0 0})$, which is less than 0.05 , indicating that the effect of this dimension is significant. Accordingly, we reject the second null hypothesis, and accept the alternative hypothesis: There is an effect at the level of $(\alpha \leq 0.05)$ for Possessiveness and Implementation in reducing the risk of cloud computing (Identity and Access Management, Data protection, Virtual operating risk, IT support, and Organization) In the Jordanian industrial companies public shareholding from the perspective of Jordanian Certified Public Accountants.

The table of coefficients showed that the value of B at (Support and Delivery) reached $(0.128)$ and that the value of $\mathrm{T}$ is $(\mathbf{. 3 1 5 5})$ with level of significance $(\mathrm{Sig}=\mathbf{0 . 0 0 2}$ ), which is less than 0.05 , indicating that the effect of this dimension is significant. Accordingly, we reject the third null hypothesis, and accept the alternative hypothesis: There is an effect at the level of $(\alpha \leq 0.05)$ for Support and Delivery in reducing the risk of cloud computing (Identity and Access Management, Data protection, Virtual operating risk, IT support, and Organization) In the Jordanian industrial companies public shareholding from the perspective of Jordanian Certified Public Accountants. 
The table of coefficients showed that the value of B at (Monitoring and Evaluation) reached (0.160) and that the value of $\mathrm{T}$ is (2.141) with level of significance ( $\mathrm{Sig}=\mathbf{0 . 0 3 4}$ ), which is less than 0.05 , indicating that the effect of this dimension is significant. Accordingly, we reject the forth null hypothesis, and accept the alternative hypothesis: There is an effect at the level of $(\alpha \leq 0.05)$ for Monitoring and Evaluation in reducing the risk of cloud computing (Identity and Access Management, Data protection, Virtual operating risk, IT support, and Organization) In the Jordanian industrial companies public shareholding from the perspective of Jordanian Certified Public Accountants.

The table of coefficients showed that the value of B at (Guidance and Control) reached (.0234) and that the value of $\mathrm{T}$ is (3.079) with level of significance ( $\mathrm{Sig}=\mathbf{0 . 0 0 2}$ ), which is less than 0.05 , indicating that the effect of this dimension is significant. Accordingly, we reject the fifth null hypothesis, and accept the alternative hypothesis: There is an effect at the level of $(\alpha \leq 0.05)$ for Guidance and Control in reducing the risk of cloud computing (Identity and Access Management, Data protection, Virtual operating risk, IT support, and Organization) In the Jordanian industrial companies public shareholding from the perspective of Jordanian Certified Public Accountants.

Based on the above, we reject the main null hypothesis and accept the alternative hypothesis: "There is a significant statistical effect at the level of $(\alpha \leq 0.05)$ for the decisions of the (COBIT5) Committee (Planning and Organization, Possessiveness and Implementation, Support and Delivery, Monitoring and Evaluation, and Guidance and Control)In reducing the risk of cloud computing (Identity and Access Management, Data protection, Virtual operating risk, IT support, and Organization) In the Jordanian industrial companies public shareholding from the perspective of Jordanian Certified Public Accountants".

The results of the main hypothesis test are illustrated the importance of the role of Information Technology Governance according to (COBIT 5) in minimizing the risks of cloud computing, that all these decisions will contribute to enhancing information security, ensuring their privacy and protecting the data and information contained in cloud computing, thereby protecting the company from falling prey to cybercrime attacks and hacking. To determine which of the dimensions of Information Technology Governance had the most significant effect on reducing the risk of cloud computing, the step wise regression analysis was used. The result was as follows:

Table (7). Results of step wise regression analysis

\begin{tabular}{|c|c|c|c|c|c|c|c|}
\hline Model & $\begin{array}{l}\text { Reducing the risk of cloud } \\
\text { computing }\end{array}$ & B & $\begin{array}{l}\text { Calculat } \\
\text { ed } \quad t \\
\text { value }\end{array}$ & Sig* & $\mathrm{R}^{2}$ & $\begin{array}{l}\text { Calcul } \\
\text { ated } \\
\mathrm{F}\end{array}$ & Sig* \\
\hline $\begin{array}{l}\text { First } \\
\text { Model }\end{array}$ & Monitoring and Evaluation & 0.507 & 7.564 & 0.000 & 0.249 & $\begin{array}{r}57.20 \\
7\end{array}$ & 0.000 \\
\hline Second & \multirow{2}{*}{$\begin{array}{l}\text { Monitoring and Evaluation } \\
\text { Planning and Organization }\end{array}$} & 0.350 & 4.952 & 0.000 & \multirow{2}{*}{0.341} & 44.41 & \multirow{3}{*}{0.000} \\
\hline Model & & 0.237 & 4.901 & 0.000 & & 8 & \\
\hline \multirow{3}{*}{$\begin{array}{l}\text { Third } \\
\text { Model }\end{array}$} & Monitoring and Evaluation & 0.297 & 4.295 & 0.000 & \multirow{3}{*}{0.397} & \multirow{3}{*}{$\begin{array}{r}37.46 \\
7\end{array}$} & \\
\hline & Planning and Organization & 0.226 & 4.866 & 0.000 & & & \multirow{2}{*}{0.000} \\
\hline & $\begin{array}{l}\text { Possessiveness } \\
\text { Implementation }\end{array}$ & 0.173 & 3.985 & 0.000 & & & \\
\hline \multirow{5}{*}{$\begin{array}{l}\text { Fourth } \\
\text { Model }\end{array}$} & Monitoring and Evaluation & 0.263 & 3.855 & 0.000 & \multirow{5}{*}{0.431} & \multirow{5}{*}{$\begin{array}{r}32.17 \\
2\end{array}$} & \multirow{5}{*}{0.000} \\
\hline & Planning and Organization & 0.178 & 3.744 & 0.000 & & & \\
\hline & $\begin{array}{l}\text { Possessiveness } \\
\text { Implementation }\end{array}$ & 0.185 & 4.368 & 0.000 & & & \\
\hline & Support and Delivery & 0.133 & 3.198 & 0.002 & & & \\
\hline & Monitoring and Evaluation & 0.160 & 2.141 & 0.034 & & & \\
\hline \multirow[b]{2}{*}{$\begin{array}{r}\text { Fifth } \\
\text { Model }\end{array}$} & Planning and Organization & 0.146 & 3.074 & 0.002 & \multirow[t]{2}{*}{0.461} & \multirow{2}{*}{$\begin{array}{r}28.91 \\
7\end{array}$} & \multirow[t]{2}{*}{0.000} \\
\hline & $\begin{array}{l}\text { Possessiveness } \\
\text { Implementation }\end{array}$ & 0.185 & 4.459 & 0.000 & & & \\
\hline
\end{tabular}




\begin{tabular}{llrr}
\hline Support and Delivery & $\mathbf{0 . 1 2 8}$ & $\mathbf{3 . 1 5 5}$ & 0.002 \\
Guidance and Control & $\mathbf{0 . 2 3 4}$ & $\mathbf{3 . 0 7 9}$ & 0.002 \\
\hline
\end{tabular}

*The effect is statistically significant at level $(\alpha \leq 0.05)$

The results of the regression analysis show the order of entry of variables in the regression model that represents the effect of the decisions of Information Technology Governance on reducing the risk of cloud computing. Where it was found that monitoring and Evaluation ranked first, and explained $(0.249 \%)$ of the variance in the dependent variable. When (Planning and Organization) add in the second model, the explanation ratio increased to $(0.341 \%)$. The addition of (Possessiveness and Implementation) led to a high rate of interpretation to reach $(0.397 \%)$. Adding (Support and Delivery) increased the interpretation of $(0.431 \%)$. And finally when (Guidance and Control) added the explanation ratio increased to $(0.461 \%)$. We note that the effect of all independent variables had a significant effect at a level of significance less than 0.05 .

\section{Conclusions}

The results of the analysis of the study data indicated that the relative importance of all Information Technology Governance and Cloud Computing Risks are high, which indicates that the management of the industrial companies is interested in monitoring the company's operations and information technology to ensure compliance with the policies, strategies, laws, and regulations in this area as well as seeking to reduce the risks and threats generated by the use of technology and the efficiency and effectiveness of their procedures in order to reduce these risks and reduce the negative impact and damage to the company and its customers.

The results of the main hypothesis test are illustrated the importance of the role of Information Technology Governance in terms of their combined dimensions in minimizing the risks of cloud computing, forasmuch all dimensions will contribute to enhancing information security, ensuring their privacy and protecting the data and information contained in cloud computing, thereby protecting the company from falling prey to cybercrime attacks and hacking. The also study concluded that all the Information Technology Governance including planning and organization, possessiveness and implementation, support and delivery, monitoring and evaluation, and Guidance and Control affect the reduction of the risk of cloud computing in terms of identity and access management, data protection, virtual operating risk, IT support, and organization in the Jordanian industrial companies public shareholding from the perspective of Jordanian Certified Public Accountants.

Based on the findings of the study, the study recommends that Jordanian industrial companies should establishment of a special department for human resources management, which will have a pioneering intellectual direction for their development within the company to face the risks associated with the use of cloud computing. As well as the need to activate the role of security controls of all types (preventive, exploratory and corrective) and increase the level of application against the environmental risks surrounding the company likely to occur as a result of the application of cloud computing. It is also necessary to update and develop information technologies, especially those related to technology, because of their role in maintaining the continuity of the company in proportion to its current and future plans. And the need for companies to identify security risks in cloud computing in order to obtain a clear picture of sound internal controls and related responses that the company should take to ensure that the company's business continues smoothly without fear of data disruption.

\section{References}

Abdel Basset, A. (2014). COBIT 5 as A Mechanism for it Governance: A Case Study of State Oil Company. Unpublished Master Thesis, Abou Bekr Belkid University, Tlemcen, Algeria.

Aljoumah, E., Al-Mousawi, F., Ahmad, I., Al - Shammri, M., \& Al - Jady, Z. (2015). SLA in Cloud Computing Architectures: A Comprehensive Study. International Journal of Grid Distribution Computing, 8(5), 7 - 32, https:// DOI: 10.14257/ijgdc.2015.8.5.02.

Alkhalil, A., Sahandi, R., \& Opara, M. J. (2013). Cloud Computing From SMES Perspective: A Survey - Based Investigation. Journal of Information Technology Management, XXIV(1), 1 - 12.

Alslihat, N., Matarneh, A. J., Abdul, M., Usama, A. H., \& Al - Rawashdeh, N. (2018). The Impact of Internal Control System Components of the COSO Model in Reducing the Risk of Cloud Computing: The Case of Public Shareholding Companies. Journal of Science and Technology, 33(4), 188 - 202.

Andry, J. F., \& Hartono, H. (2017). Performance Measurement of IT Based on COBIT Assessment: A Case Study. Journal of Indonesian Information Systems, 2(1), 1 - 13. 
Bakshi, S., \& Eswar, M. (2018). Portfolio, Program and Project Management Using COBIT 5. COBIT Focus, Part, 3, 1-6, Retrieved from http://www.isaca.org/COBIT/focus/Pages/portfolio-program-and-projectmanagement- using-cobit-5-part-3.aspx.

Behara, G., \& Srikanth, I. (2007). Approach to Service Management in SOA Space. BP Trends, February.

Bunkar, R. K., \& Rai, P. K. (2017). Study on Security Model in Cloud Computing. International Journal of Advanced Research in Computer Science, 8(7), 841 - 844. https:// DOI: 10.26483/ijarcs.v8i7.4350.

Buyya, R., Yeo, C. S., Venugopal, S., Broberg, J., \& Brandic, I. (2009). Cloud Computing and Emerging IT Platforms: Vision, Hype, and Reality for Delivering Computing as the 5th Utility. Journal of Future Generation Computer Systems, 25(6), 559 - 616. https://doi.org/10.1016/j.future.2008.12.001

Cadete, G. (2015). Using Enterprise Architecture for COBIT 5 Process Assessment and Process Improvement. Unpublished Master Thesis, Technical Superior Institute, Lisbon, Spain.

Chen, Y., Paxson, V. \&Katz, R. H. (2010). What's New about Cloud Computing Security. Technical Report, 20, University of California at Berkeley, 1 - 5.

De Haes, S., \& Van Grembergen, W. (2015). Enterprise Governance of Information Technology: Achieving Alignment and Value, Featuring COBIT 5. ( 2 nd ed.), Switzerland: Springer International Publishing.

Detlor, B., Hupfer, M. E., \& Ruhi, U. (2010). Internal Factors Affecting the Adoption and Use of Government Websites. International Journal, 7(2), 120 - 136. https://doi.org/10.1504/EG.2010.030923

Dimitriu, O., \& Matei, M. (2014). A New Paradigm for Accounting through Cloud Computing. Procedia Economics and Finance, 15, 840 - 846. https://doi.org/10.1016/S2212-5671(14)00541-3

Freeland, C. (2016). Basel Committee Guidance on Electronic Corporate Governance for Banks. Paper Presented to: Corporate Governance and Reform: Paving the Way to Financial Stability and Development, A Conference Organized by the Egyptian Banking Institute, Cairo, May, 7 - 8.

Guajarati, D. N. (2004). Basic Econometrics (4 th ed.). USA: New York: McGraw Hill.

Hardy, G. (2006). Using IT Governance and COBIT to Deliver Value with IT and Respond to Legal, Regulatory and Compliance Challenges. Information Security Technical Report, 11(1), 55-61, https://doi.org/10.1016/j.istr.2005.12.004

Iqbal, A., Jatisukamto, G., \& Mustika, I. (2016). COBIT 5 Domain Delivery, Service and Support Mapping for Business Continuity Plan. AIP Conference Proceedings, 1746, https://DOI: 10.1063/1.4953970.

ISACA (2012). COBIT 5 Framework. Retrieved from http://www.isaca.org/COBIT/Pages/COBIT-5-Frameworkproduct-page.aspx.

Krejcie, R.V., \& Morgan D. W. (1970). Determining Sample Size for Research Activities. Educational and Psychological Measurement, 30, 607-610., Retrieved from file:///C:/Users/user/Downloads/KrejcieandMorgan_article.pdf

Lee, C., Hoon, L., Jung, H., Park, J. S., \& Jeong, K. Y. (2008). Study of the Causal Relationship between IT Governance Inhibitors and Its Success in Korea Enterprises. 41 st Hawaii International Conference on System Science, 7 -10 January, Waikoloa, Big Island, HI, USA, p. 1 - 11, https://doi.org/10.1109/HICSS.2008.38

Mazhar, A., Khan, S., \& Vasilakos, A. (2015). Security in Cloud Computing: Opportunities and Challenges. Information Sciences, 305, 357 - 383.

Mehta, A., \& Panda, S. N. (2018). Design of Infrastructure as a Service (IAAS) Framework with Report Generation Mechanism. International Journal of Applied Engineering Research, 13(2), 942-946.

Michele, R., Filippo, V., \& Antonello, G. (2017). An Empirical Examination of COBIT as an Internal Control Framework for Information Technology. International Journal of Accounting Information Systems, 8(4), 240263.

Mirela, G. (2010). Audit Methodology for IT Governance. Economic Informatics, 14(1), 32 - 42.

Moeller, R. (2013). Executive Guide to IT Governance Improving Systems Processes with Service Management, COBIT and ITIL. USA, New Jersey: John Wiley and Sons Inc, Hoboken.

Mueller, L., Magee, M., Marounek, P., \& Phillipson, A. (2008). IBM IT Governance Approach Business Performance through IT Execution. International Technical Support Organization, USA.

Oliver, D., \& Lainhart, J. (2012). COBIT 5: Adding Value through Effective GEIT. The EDP Audit, Control, and 
Security Newsletter Journal, 46(3), 1 - 12.

Onyegbula, F., Dawson, M., \& Stevens, J. (2011). Understanding the Need and Importance of the Cloud Computing Environment Within the National Institute of Food and Agriculture, An Agency of the United States Department of Agriculture. Journal of Information Systems Technology and Planning, 4(8), 17 - 42.

Pastore, S. (2013). The Platform as a Service (PAAS) Cloud Model: Opportunity or Complexity for a Web Developer? International Journal of Computer Applications, 81(18), 29-37. https://doi.org/10.5120/142252435

Preittigun, A., Chantatub, W., \& Vatanasakdakul, S. (2012). A Comparison between IT Governance Research and Concepts in COBIT 5. International Journal of Research in Management \& Technology (IJRMT), 2(6), 581 -590 .

Putri, M. A., Aknuranda, I., \& Mahmudy, W. F. (2017). Maturity Evaluation of Information Technology Governance in PT DEF Using Cobit 5 Framework. Journal of Information Technology and Computer Science, 2(1), 19 - 27. https://doi.org/10.25126/jitecs.20172123.

Reddy, E. K. (2014). Information Security in Cloud Computing. International Journal of Computer Applications Technology and Research, 3(8), 510 - 514. https://doi.org/10.7753/IJCATR0308.1005.

Romero, J., Baldassarre, M., Piattini, M., \& De Guzman, I. (2017). A Governance and Management Framework for Green IT. Sustainability Journal, 9(10), 1 - 18. https://doi.org/10.3390/su9101761.

Sah, S., Shakya, S., \& Dhungana, H. (2014). A Security Management for Cloud Based Applications and Services with Diameter - $A A A$, IEEE International Conference on Issues and Challenges in Intelligent Computing Techniques (ICICT). p. 6-11. https://doi.org/10.1109/ICICICT.2014.6781243

Sasaki, T., \& Yonezawa, Y. (2010). Corporate Governance and Shareholder Value. Journal of Securities Analysts, $3(2), 39-51$.

Sen, A. K., \& Tiwari, P. K. (2017). Security Issues and Solutions in Cloud Computing. Journal of Computer Engineering, 19(2), 67-72. https://doi.org/10.9790/0661-1902046772

Shaikh, R., \& Sasikumar, M. (2013). Identity Management in Cloud Computing. International Journal of Computer Applications, 63(11), 17 - 19. https://DOI: 10.5120/10509-5467

Solomon, J. F., Lin, Sh. W., Norton, S. D., \& Soloman, A. (2003). Corporate Governance in Taiwan: Empirical Evidence from Taiwanese Company Directors. An Internatonal Review, 11(3), 23-248, https://doi.org/10.1111/1467-8683.00321.

Sun, Y., Zhang, J., Xiong, Y., \& Zhu, G. (2014). Data Security and Privacy in Cloud Computing. International Journal of Distributed Sensor Networks, 10(7), 1 - 9. https://doi.org/10.1155/2014/190903

Susanto, A. (2018). Threats on Accounting Information Systems. International Journal of Scientific and Technology Research, 7(10), 51 - 53.

Weill, P., \& Ross, J. W. (2004). IT Governance: How Top Performers Manage IT Decision Rights for Superior Results. USA: Harvard Business School Press.

\section{Copyrights}

Copyright for this article is retained by the author(s), with first publication rights granted to the journal.

This is an open-access article distributed under the terms and conditions of the Creative Commons Attribution license (http://creativecommons.org/licenses/by/4.0/). 